\title{
SHAVASANA: HARMONI DAN PENYEMBUHAN PENYAKIT TUBUH DAN PIKIRAN
}

\author{
Oleh:
}

I Made Adi Surya Pradnya

Dosen Pascasarjana IHDN Denpasar

\begin{abstract}
:
Present era, people are faced with competition of various aspects, resulting in a culture of high tension. The tension that occurs causes the anatomy of the body is disturbed, even the damage that causes the balance of the body and mind problems. This disharmony becomes a common illness, stress, a psychosomatic disorder that can only be healed through inward healing or relaxation. Yoga is one method to overcome the problem and restore harmony between body and mind, so it can be felt directly on health. Asana is part of yoga. Asana has many postures. For deep relaxation can be done with shavasana. Through the shavasana the body and mind enter into relaxation and release the tension from the whole anatomy of the body. Similarly, shavasana can cure stress because replacing the negative emotional sediment in the self into a positive emotion. Stress occurs when a person can not solve the problem that comes due to the difference between the desire with reality. Therefore, shavasana through proper relaxation and breathing and done at the right time, psychosomatic illness can be cured.
\end{abstract}

\section{Keywords: Shavasana, Harmony of body and mind}

\begin{abstract}
ABSTRAK:
Era zaman now, manusia dihadapkan pada persoalan hidup yang begitu ketat dengan persaingan dan kompetisi berbagai aspek, sehingga melahirkan budaya tegangan tinggi. Ketegangan yang terjadi menyebabkan anatomi tubuh terganggu, bahkan terjadi kerusakan yang menyebabkan keseimbangan tubuh dan pikiran bermasalah. Ketidakharmonisan ini menjadi penyakit yang banyak dihidap masyarakat, yddddraitu stress, sebuah gangguan psikosomatis yang hanya dapat disembuhkan melalui penyembuhan ke dalam, yaitu relaksasi. Yoga adalah salah satu metode untuk mengatasi masalah tersebut dan mengembalikan keharmonisan antara tubuh dan pikiran, sehingga dapat dirasakan langsung pada kesehatan. Asana adalah bagian dari yoga, asana memiliki banyak postur, untuk relaksasi yang mendalam dapat dilakukan dengan shavasana. Melalui shavasana tubuh dan pikiran masuk dalam relaksasi dan melepaskan ketegangan dari seluruh anatomi tubuh. Begitu pula shavasana, dapat menyembuhkan penyakit stress, karena menggantikan endapan emosi negatif dalam diri menjadi emosi positif. Karena stress terjadi ketika seseorang tidak dapat mengatasi masalah yang datang akibat perbedaan antara keinginan dengan kenyaataan. Oleh karena itu, shavasana melalui relaksasi dan pernafasan yang tepat dan dilakukan pada waktu yang tepat, penyakit psikosomatis dapat disembuhkan.
\end{abstract}

Kata Kunci: Shavasana, Harmoni tubuh dan pikiran

\section{PENDAHULUAN}

Perkembangan pengetahuan dan teknologi menyebabkan kehidupan manusia menjadi keras, sehingga persaingan semakin ketat. Inilah yang menyebabkan penyakit stress membuat tubuh dan pikiran tidak harmonis. Efek stress menyebabkan penyakit psikis dan fisik. Inilah ciri kehidupan saat ini yang disebut kebudayaan tegangan tinggi (high tention culture), dimana masyarakat modern memburu keuntungan komersil dan penuh rivalitas yang mengandung unsur ekplosif, mudah pecah dan meledak dalam bentuk tindakan kekerasan, amuk, tindakan nekad dan nyerempet bahaya, asusila, kriminal, koruptif, mengacau, memberontak dan sebagainya (Kartini, 2013: 274).

Akibat dari ketegangan yang terus menerus menyebabkan organ-organ tubuh tidak seimbang, 
dimana ia ingin membuat keputusan, namun ia tidak bisa melakukanya. Begitu pula sebaliknya ketika ia telah berhasil mengambil keputusan, namun tidak dapat menyelesaikanya. Inilah konflik yang terjadi, sehingga seluruh tubuh dan organ tubuhnya bermasalah yang lama kelamaan mengendap menjadi penyakit psikosomatis yang tidak dapat disembuhkan melalui pengobatan medis, karena bermasalah secara psikologis (Gunawan, 2012: 88). Fakta dan realita dapat ditemukan dengan logika berpikir, semakin banyak dibangun rumah sakit, semakin banyak pula pasien yang dating berobat. Bahakan di Bali dibangun beberapa rumah sakit bertaraf internasional, dan pasien pun semakin banyak.

Seseorang seseungguhnya dilahirkan untuk bahagia dan Tuhan telah menciptakan anatomi tubuh yang serba otomatis. Tubuh memiliki mekanismenya sendiri dan memberikan respon terhadap stimulus yang masuk dalam pikiran yang mempengaruhi anatomi tubuh. Namun ketika tubuh tidak kuat menahan masalah yang dihadapai, maka terjadilah distress yang mempengaruhi tubuh, dimana ia merasakan detak jantung berdebar-debar; sesak nafas; gumpalan lendir di tenggorokan, nafas pendek, dan cepat; mulut kering, gangguan pencernaan, diare, sembelit, gembung perut (flatulensi); ketegangan otot secara keseluruhan khususnya rahang dan kerak gigi; kegelisahan, hyperaktif, menggigit kuku, mengetok jari, menginjak-injakan kaki, meremas remas tangan; Lelah, capek, lesu, sulit tidur, merasa sedih, sakit kepala, sering sakit, seperti flu; berkeringat khsusunya di telapak tangan dan bibir atas, merasa gerah; tangan dan kaki dingin; sering ingin kencing; makan berlebihan, kehilangan selera makan, merokok lebih banyak; makin banyak minum alcohol, hilangnya ketertarikan pada seks (Looker \& Gregson, 2005: 111-112).

Ketidakharmonisan tubuh dan pikiran yang disebabkan lemahnya mental karena pengaruh dari luar maupun dalam diri, mendorong seseorang untuk dapat mengatasi setiap persoalan dalam hidup, khusunya dalam mengelola masalah sehingga tidak stress, melainkan mampu mengelola masalah, sehingga menjadi lebih damai, bahagia dan harmonis, antar diri, lingkungan maupun pada alam semesta. Inilah sesungguhnya esensi dari konsep Tri Hita Karana, yaitu keharmonisan manusia dengan Tuhanya (parhyangan), keharmonisamn manusia dengan lingkunganya (palemahan) dan keharmonisan manusia dengan manusia lainya (pawongan). Sebelum mencapai keharmonisan yang disebutkan dalam konsep Tri Hita Karana, maka damaikan, harmoniskan diri sendiri.

Mengharmoniskan diri sendiri tidak dapat dilakukan secara bersama-sama namun dilakukan dengan diri sendiri yaitu melalui disiplin diri yang disebut sadhana. Melalui sadhana inilah mencari hakikat dan kebenaran sejati untuk mendapatkan pencerahan dan kesadaran. Keadaan sadhana yang dimaksudkan adalah mereka yang belajar memahami Tuhan yang ada di dalam dirinya sendiri dan inilah yang dimaksudkan agar dapat memahami kebenaran yang melampaui pikiran. Dengan demikian, tidak setiap masalah yang dihadapi dapat diatasi dengan mudah dan tercipta keharmonisan dari dalam diri.

Sadhana yang baik dilakukan sesuai dengan ajaran Hindu, yaitu melakukan sadhana yoga. Filsafat hindu atau filsafat india, menjelaskan pengetahuan yoga melalui pemikiran Maharsi Patanjali, sehingga dikenal dengan Yoga Sutra Patanjali, namun banyak lagi yoga dalam teksteks Hindu. Termasuk pula dalam teks Hindu di Nusantara, seperti Ganapati tattwa, tattwa jnana, juga dijelaskan tentang sadanggayoga atau astanggayoga.

Salah satu dari astangga yoga adalah asana, yang merupakan posture yang penuh kesadaran dan rileks. Asana means "seat" and refers to the art of body postures that have ovelved over many centuries. Apart from cultivating kanti (physical beauty) due to the enhanced pranic flow (life energy) through the body, asanas remove fickleness of mind to restore mental and physical health, strength, wellbeing and vitality. Asanas practice also reflects the tendencies, strengths, weaknesses and action in our life (Jean \& Doriel, 2015: 11). Yoga asana adalah gerakan tubuh yang dapat membangkitkan energi, sehingga tercipta keseimbangan antara tubuh, pikiran dan jiwa, yang memberikan kekuatan pada kesehatan, kesadaran dan action dalam kehidupan. 
Asanas begitu banyak bentuknya, baik dari posisi duduk, berdiri, berbaring dan sebagainya, semua postur asanas berpengaruh terhadap anatomi tubuh, karena tubuh berpengaruh terhadap pikiran dan jiwa. Begitu pula shavasana merupakan postur yoga yang sangat "digemari" karena dapat dilakukan dengan mudah oleh siapapun dan dimanapun, meskipun demikian manfaat shavasana juga sangat penting untuk memberikan keharmonisan tubuh dan pikiran, sehingga tercipta manusia yang sehat, secara fisik maupun mental. Shavasana juga dapat memberikan kesehatan yang paling penting pada zaman now, yaitu penyembuhan terhadap penyakit psikosomatis yaitu stress.

\section{PEMBAHASAN}

\subsection{Shavasana Harmoniskan Tubuh dan Pikiran}

Perkembangan yoga saat ini semakin digemari oleh banyak kalangan, bahkan menjadi life style masyarakat lintas agama, suku, ras dan golongan. Beberapa festival telah dilaksanakan dan kini yoga telah mendunia. Begitu juga asanas telah banyak dipraktikan dan terlihat begitu mudah dilakuakn. Yoga telah menyatukan perbedaaan dan memberikan terobosan bagi masyarakat kebermanfaat yoga untuk kesehatan badan, karena kesehataan adalah sesautu yang sangat penting dari apapaun, bahkan beberapa orang menghabiskan uangnya hanya untuk menjaga kesehatan. Inilah satu alasana yoga begitu dicintai sampai kapanpun.

Shavasana berasal dari Bahasa Sanskrit yang terdiri dari kata shava berarti mayat dan asana adalah postur, secara harfiah Shavasana adalah salah satu bentuk postur dalam yoga, seperti postur mayat. Hal ini sesuai dengan The Encyclopedia Of Yoga and Tantra, shava-asana is dead posture, synonym for mrita-asana (Feuerstein, 2011: 336). Shavasana disebut juga memasuki alam pikiran deep relaksasi dan merupakan gerakan terakhir dari kelas yoga, shavasana terlihat begitu sangat mudah dilakukan, namun sesungguhnya tidak sekedar tertidur melainkan diperlukan kesadaran. Hal ini sesuai dengan pendapat McCall (2007: 59) shavasana is sometimes called Deep relaxation, it's typically the last posture of yoga class. While it looks easy, yogis insist shavasana is the most difficult pose to do well-and the most important. Savasanas is nothing like taking a nap or lying around on the couch. Those activities tend to bring dullness to the mind, whay yogis refer to as a tamasic state. In savasana, youa are not spacing out, you are tuning in with evermore subtlety to what is going on. This is sattvic, or clear, state of mind.

Shavasana untuk mengharmoniskan tubuh sangat mudah dilakukan, namun perlu dipahami step-step melakukanya, karena metode shavasanas adalah metode relaksasi, sehingga seluruh organ tubuh, otot-otot, panca indra dan semuanya dikendurkan dan dibiarkan santai tanpa ketegangan. Rasakan lepasnya ketegangan dari ujung rambut masuk pada kepala, kemudian turun ke kerongkongan, sehingga tubuh semakin rileks, semakin santai. Rasakan kembali rongga dada terasa ringan dan bebas dari ketegangan, selanjutnya rasakan perut, dan daerah pencernaan lainya berlahan-lahan mulai rileks dan santai, lakukan dengan bernafas yang santai dan dapat pula dilakukan sambil tersenyum. Selanjutnya rasakan energi rilaksasi turun pada tulang ekor dan sekitarnya, sehingga semakin rileks semakin damai. Selanjutnya rasakan energi kedamaian turun ke seluruh paha kiri dan kanan, lutut, telapak kaki, sehingga seluruh tubuh semakin santai, rileks dan keharmonisan berlahan-lahan terasa dalam tubuh. Lakukan shavasana ini selama 10-15 menit dengan memperhatikan nafas keluar dan masuk dan tetap tersenyum. Shavasana dapat dilakukan seperti gambar di bawah ini:

Gambar 1.1

Shavasana Harmoniskan Tubuh

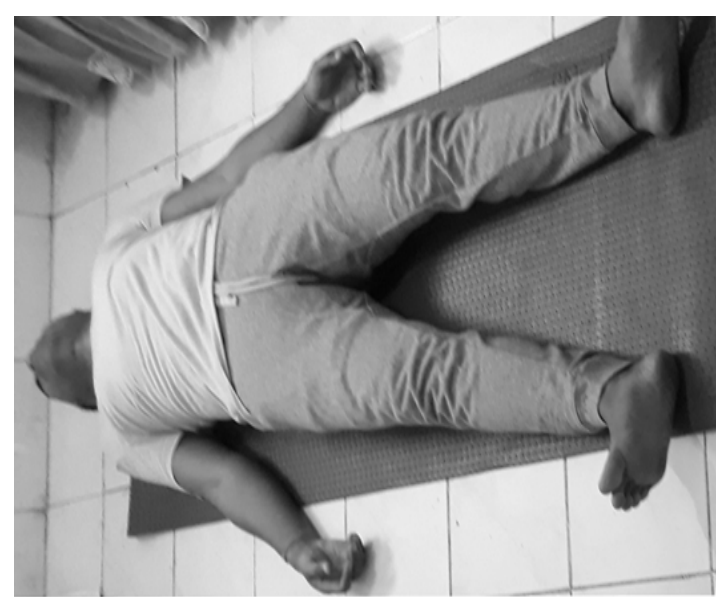

Sumber: Penulis, 2018 
Shavasana untuk menciptakan harmoninya tubuh, dilakukan dengan tidak bergerak selama melakukan shavasana, perhatikan nafas dan rasakan relaksasi dari ujung rambut sampai ujung kaki, sehingga tujuan dan manfaat shavasana tercapai. Selain itu, agar tetap dalam kesadaran, maka dapat mengucapkan mantra, seperti gayatri mantra atau namasmaranam lainya, sehingga pikiran mulai terfokus dan berada dalam keadaan beyond of mind. Untuk keuntungan maksimal, teknik ini sebaiknya dilakukan setelah bekerja keras seharian, sebelum kegiatan malam hari, atau untuk menyegarkan tubuh dan pikiran sebelum duduk bermeditasi, atau sesaat sebelum tidur. Hal ini disebutkan juga oleh Swami Satyananda Saraswati (2012: 87), sebagai berikut:

Do not move the body at all during the practice as even the slightest movement disturbs the practice. A personal mantra may be repeated with every inhalation and exhalation. For maximum benefit, this technique should be performed after a hard day's work, before evening activities, or to refresh the body and mind before sitting for meditation, or just before sleep.

Keadaan deep relaksasi inilah yang disebut kesadaran pikiran memasuki gelombang otak alpha, theta dan juga deltha. Shavasana adalah cara mencapai ini, sebab selama dalam kehidupan sehari-hari yang dihadapkan pada persaingan hidup yang keras, menyebabkan ketegangan seluruh tubuh, sehingga jika tidak mampu mengatasinya, endapan emosi menjadi penyakit. Pada saat mengalami ketegangan itulah, gelombang otak berada dalam gelombang beta (14-20 Hz), yaitu gelombang berada dalam pikiran sadar. Begitu juga sebaliknya ketika seseorang berada dalam keadaaan relaks, gelombang otak yang dominan bergeser dari Beta ke Alpha (8-13,9 $\mathrm{Hz}$ ), gelombang alpha muncul saat pikiran sadar mulai pasif dan sebaliknya pikiran bawah sadar mulai aktif, sehingga seseorang dapat merasakan kondisi relaks pada tubuh dan pikiranya. Begitu pula seterusnya saat relaksasi lebih mendalam, maka bergeser dari alpha menuju theta (4-7,9 $\mathrm{Hz}$ ), sehingga pikiran bawah sadar benar-benar mengambil alih pikiran sadar. Terakhir ketika relaksasi terjadi lebih mendalam lagi inilah gelombang otak Delta (0,1-3,9 Hz) memasuki tidur yang sangat nyenyak (Wong dan Hakim, 2010, 21-22).

Gambar 1.2

Gelombang Otak dan Tingkat Kesadaran

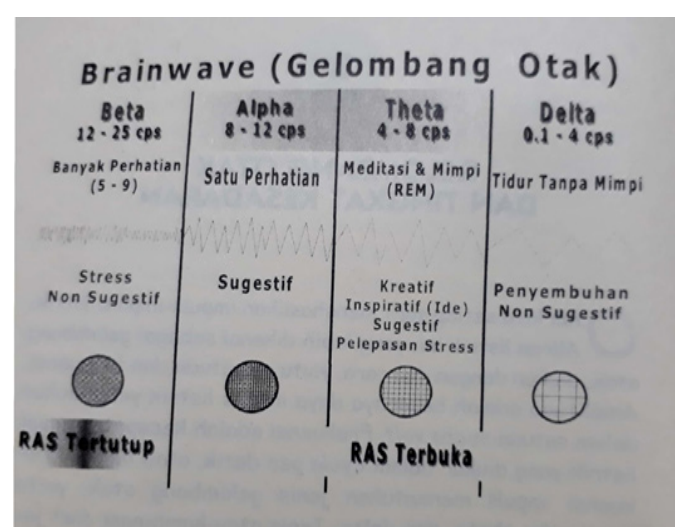

Sumber: (Gunawan, 2012: 54)

Praktik shavasana sesungguhnya adalah asanas yang sangat penting yaitu dapat memasuki gelombang pikiran manusia yang mendalam, serta mampumemberikanrelaksasiuntuk penyembuhan, penyegaran seluruh anatomi tubuh, sehingga dapat bergerak dan bekerja secara alamiah. Shavasana juga sebagai jembatan penghubung antara pikiran manusia dengan pikiran semesta yang agung, sehingga ketika seseorang telah terhubung melalui nafas dan selama melakukan relaksasi, maka keharmonisan antara pikiran dan tubuh dapat terjaga dengan baik, karena pikiran dan tubuh tidak dapat dipisahkan, keduanya saling berpengaruh antara satu dengan lainya.

Herbert Spencer melakukan ekperimen pada mahasiswanya di Fakultas Kedokteran, Universitas Harvard, Amerika Serikat, kemudian menyimpulkan bahwa apa yang anda pikirkan dan katakan pada diri anda diambil oleh otak. Selanjutnya ia membuka data-data yang sesuai dengan apa yang anda pikirkan. Ketika itulah pikiran anda mempengaruhi gerakan tubuh dan ekspresi wajah. Jadi seseorang bisa merasakan bahwa tubuhnya dipengaruhi oleh pikiranya (Elfiky, 2014: 27). Oleh karena itu, shavasana dapat mengharmoniskan seluruh anatomi tubuh dan berkorelasi untuk mengharmoniskan pikiran, dengan demikian tercipta kedamian dan kebahagiaan semua mahluk. 


\subsection{Shavasana Untuk Penyembuhan Stress}

Definisi stress adalah sebuah keadaan yang di alami ketika ada sebuah ketidaksesuaian antara tuntutan-tuntutan yang diterima dan kemampuan untuk mengatasinya (Looker \& Gregson, 2005: 44). Hans Selye (dalam Sugara, 2016: 81) mendefinikan stress sebagai reaksi nonspesifik tubuh terhadap ancaman, dimana ketika mampu beradaptasi dengan ancaman itu dsebut eutress (stress yang sehat), jika tidak bisa beradaptasi disebut distress (stress yang tidak sehat). Lebih lengkapnya lagi, secara teknis stress dibagi menjadi empat, yaitu eustress, distress, hyperstress dan hypostress. Yang disebut eustress adalah stress jangka pendek, bersifat positif, karena melahirkan kreaticvitas, antusias, motivasi, sedangkan distress adalah stress yang terlalu dipandang berat dan sulit untuk diatasi. Hyperstress adalah stress yang terjadi karena seseorang terdorong melampaui kemampuanya untuk bertahan dan mengatasi tekanan, cepat meledak, marah besar atau menangis hebat. Berbeda dengan hypostress yaitu seseorang yang merasa hidupnya selalu monoton, tidak ada tantangan dan membosankan, orang seperti ini sering gelisah, apatis dan tidak bersemangat (Gunawan, 2012: 117-118).

Bagan 2.1

Penyebab Stress

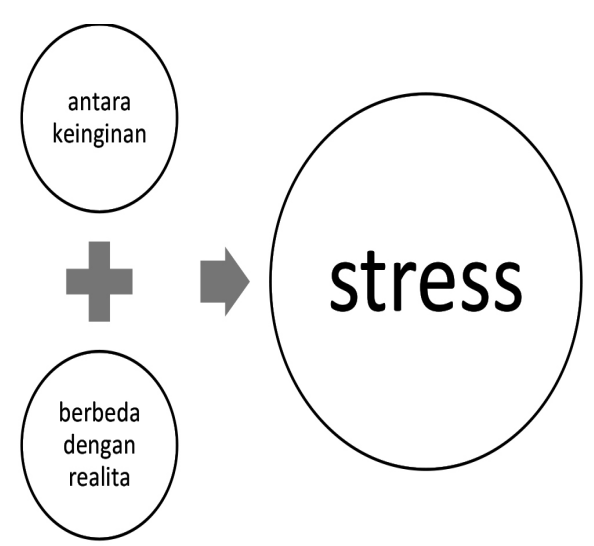

Berdasarkan bagan di atas 2.1 kesimpulan sederhananya, ketika adanya kesenjangan antara keinginan, harapan dengan realita atau fakta tidak sesuai, inilah menimbulkan masalah dan ketika masalah muncul, maka disinilah kemampuan untuk mengelola masalah diuji. Jika tidak mampu mengatasi dengan benar, maka terjadilah stress.
Ketidakmampuan dalam mengelola masalah menyebabkan ketidakseimbangan tubuh, pikiran, jiwa dan mental. Bahkan Dr. Candace Pert, neuroscientist, menyatakan di awal penelitianya ia berasumsi bahwa emosi hanya terjadi pada otak atau kepala, namun temuan penelitianya adalah emosi sebenarnya ada di tubuh fisik manusia. Saat seseorang mengalami emosi tertentu yang terjadi sebanarnya ia merasakan reaksi kimia di tubuh dan di otaknya, reaksi kimia terjadi di level organ, seperti lambung, jantung, dan otot-otot besar maupun di level sel. Lambung dan usus sangat sesitif terhadap stress yang disebakan emosi dan kedua organ ini adalah tempat kecemasan (Gunawan, 2012: 121).

Oleh karena itu, salah satu metode penyembuhan penyakit stress disebabkan ketegangan, kecemasan, ketakutan, tekanan, yang mengendap pada pikiran bahwa sadar, sehingga memicu tindakan yang menyebakan sakit tidak dapat disembuhkan melalui medis. Pengaruh psikosomatis mengarah pada penyakit organis perlu mendapat penangan serius melalui pendekaran psikosomatis, karena sumber masalahnya ada pada kesalahan berpikir yang kemudian menjadi belief system. Selain belief system istilah mental block juga menghambat komunikasi pikiran bawah sadar menuju pikiran sadar, selama mental block tidak dibereskan, maka apapun yang dikerjakan akan sulit berhasil karena mental block menyabotase segala upaya, mental block adalah biang keladi dari pencapaian hidup yang rendah (Gunawan, 2015: 105). Diperlukan metode mengubah belief system lama menjadi baru serta mental block pasien stress melalui Yoga, salah satunya dengan Shavasana, sehingga semua system dalam tubuh dapat disembuhkan karena penyakit psikosomatis yang mengendap, menyebakan kerusakan dalam anatomi tubuh dengan gejala-gejala psikosomatis dapat menyebabkan sakit yang dapat mematikan, salah satunya jantung, maag kronis, kangker dan penyempitan pembuluh darah. Saat merasa khawatir, cemas mengenai sesuatu hal, maka perut menjadi tidak nyaman, sakit kepala, depresi dan ketidakbahagiaan membuat tubuh terasa berat dan lemas, tidak berenergi, kehilangan nafsu makan atau bahkan makan berlebihan, sakit punggung atau pundak terasa kaku (Gunawan, 2012: 19). 
Hal ini juga disebutkan McCall dalam buku Yoga as Medicine (2007: 58), bahwa yoga sangat efektif untuk menyembuhkan stress dan menyeimbangkan kembali tubuh, pikiran dan jiwa, meskipun ada beberapa gerakan yoga yang membuat tidak nyaman, tapi sangat berpengaruh terhadap sumber stress, sehingga berlahan tapi pasti kesembuhan terjadi.

The regular practice of yogic postures can be a fabulous way to lower stress, when you feel overwhelmed, and as preventive medicine. Besides changing the balance of the nervous system, asana reduces muscle tension. From a yogic perspective, stress can cause muscle spasms and the reverse is also true: thight muscles can raise your stress levels. Thus varied asana program is an effective way to gradually lessen this cronic source of stress, even if some of the postures don't necessarily feel relaxing while you are doing them.

Oleh karena itu, McCall (2007: 59) menyebutkan Sharvasana adalah asana yang dapat digunakan untuk menyembuhkan stress, dimana dilakukan dengan berbaring dengan santai dan rileks tangan kanan dan kiri terbuka menghadap ke atas dan kaki kiri dan kanan biarkan terbuka. Kemudian tutup mata dengan santai dan relaks, rasakan relaksasi semakin mendalam. Berlahanlahan aturlah nafas agar semakin mendalam, kemudian berlahan-lahan buka sedikit mulut sehingga ada rongga antara gigi atas dan bawah mengikuti terbukanya mulut yang sedikit terbuka. Setiap tarikan nafas membuat semakin dalam dan lebih rileks, santai. Kendurkan otot-otot di bahu sampai ke seluruh tubuh, yang anda rasakan adalah kebahagiaan, sambil bernafas biasa, yang paling penting dari postur ini adalah relaksasi yang mendalam, namun perlu kesadaran mengontrol, sehingga tidak sampai tertidur. Ideally, you should not fall asleep in relaxation pose. The goal is a state of relaxed awareness. If you do fall asleep, it's a sign you are sleep deprived. Sleeping in relaxation pose isn't yoga but the sleep may be useful.

Pernafasan adalah hal yang sangat penting dalam yoga begitu pula untuk mendapatkan relaksasi yang mendalam, ada beberapa teknik yang baik dilakukan untuk mendapatkan manfaat dari shavasana, seperti yang disampaikan Swami Satyananda Saraswati (2012: 86), pernafasan dilakukan secara alamiah dan santai atau dilakukan dengan menghitung keluar masuknya nafas, sehingga pikiran sadar, berlahan-lahan tidak aktif dan telah tercapai relaksasi yang mendalam.

Natural and relaxed, or begin to count the breaths from number 27 backwards to zero. Mentally repeat, "I am breating in 27. I am breating out 27. Iam breating in 26. I am breating out 26" and so on, back to zero. If the mind wanders and the next number is forgotten, bring it back to the counting and start again at 27. If the mind can be kept on the breath for a few minutes, the body will relax.

Tampaknya untuk mendapatkan relaksasi mendalam seperti yang disampaikan di atas, juga memiliki kesamaan dalam proses hypnotherapy yaitu membawa seseorang pada level kesadaran tertentu, sehingga merubah belief system lama menjadi yang terbaru, sehingga luapan emosi atau endapan emosi dapat digantikan dengan emosi yang positif. Pada proses hypnotherapy juga mengenal istilah deeping yaitu teknik yang bertujuan membawa subjek jauh lebih dalam lagi dan memberikan sentuhan imajinasi (Wong \& Hakim, 2010: 42). Berikut salah satu relaksasi deepening dalam hypnotherapy bagi penyembuhan stress.

Saya akan menghitung turun dari 10 ke 1. Pada setiap hitungan turun, anda menjadi semakin dua kali rileks dari hitungan sebelumnya. Semakin turun, anda semakin rileks. Setiap hitungan mundur membuat anda dua kali semakin rileks dari hitungan sebelumnya... 10.. 9... dua kali lebih rileks... 8... dua kali lebih rileks dari sebelumnya... 7... dua kali lebih rileks... 6.. 5.. dua kali lebih rileks... terus lakukan hitungan sampai angka 1 (Gunawan, 2012: 126).

Dijelaskan pula pentingnya pernafasan dalam yoga, karena setiap nafas memberikan ketegangan keluar melalui kulit, otot, tulang, sel dengan demikian terjadilah relaksasi pikiran yang terjadi melalui relaksasi tubuh. Hal ini sesuai dalam The Enscyclopedia Of Astangga Yoga and Meditation (2015: 128) yang menyebutkan pernafasan dapat 
merelaksasikan ketegangan, sehingga tercipta kesadaran dan pencerahan.

Breath by breath in savasana, let tention flow out from your skin, muscle, organs, bones and cells, counsciously relaxing your mind by counsciously relaxing by your body. The series has cleansed, unblocked and released your body and mind from stagnant energy, tensions and toxin. Now the purified body may rest unburdened in this clear open space. Listen within to the sound of your breath, the sensation of your body, the counsciousness of your mind and the awareness of your heart. As you relax in savasana, the parasympathetic (relaxatory) and sympathetic (excitatory) nervous system balance, inducing a state of yogic sleep (yoganidra). This enables you to discover an internal sanctuary of deep relaxation with inner awareness. This is a form of pratyahara, wgich lead the way to a higher realization.

Untuk mendapatkan relaksasi yang lebih mendalam dan baik untuk kesehatan, maka ada empat syarat penting yang harus dipenuhi, yaitu 1).Lingkungan yang tenang, misalnya dalam ruangan atau kamar yang tenang sangat membantu mudah masuknya ke kondisi relaksasi. 2). Sebuah piranti mental, untuk dapat focus, maka diperlukan media, seperti music, suara, kata, atau kalimat yang diulang baik dalam hati atau dengan suara yang keras, bisa juga dilakukan dengan focus menatap pada sebuah objek. 3).Sikap pasrah dan pasif, artinya hanya perlu menyadari pikiran yang dating dan masuk serta tidak berhenti mengucapkan kata yang diulang atau memandang sebuah objek. 4). Posisi yang nyaman, saat melakukan relaksasi, maka pastikan tubuh nyaman tanpa ketegangan (Gunawan, 2012: 285-286). Berdasarkan hal demikian, penderita stress dapat melakukan shavasana setiap waktu, sehingga ketegangan menjadi relak dan otot maupun organ dapat berjalan dengan baik dan penyembuhan terjadi.

\section{PENUTUP}

Shavasana mampu memberikan keharmonisan pada tubuh dan pikiran, kedua ini sangat mempengaruhi kehidupan. Apabila keduanya tidak seimbangan, maka menyebabkan penyakit psikosomatis yang dapat berubah menjadi penyakit medis. Inilah yang banyak terjadi di masyarakat, sehingga shavasana baik dilakukan disamping posturnya tidak terlalu sulit, karena Shavasana dilakukan seperti orang tertidur, yaitu berbaring dan memperhatikan nafas, rasakan seluruh ketegangan dari ujung rambut berlahan-lahan terasa relak dan santai sampai ujung kaki, sehingga terjadi perpindahan gelombang pikiran dari Bheta menuju alpha atau theta dan delta. Ketika terbangun dari shavasana, tubuh terasa segar dan fresh, namun disarankan melakukan shavasana dalam keadaan sadar, tidak lelap tertidur.

Penyakit psikosomatis yaitu stress, dapat disembuhkan dengan shavasana, apabila dalam keadaan gelisah, cemas, ketakutan, marah, dendam, benci dan emosi lainya, maka segera lakukan shavasana, yaitu mencari tempat yang tenang, kemudian berbaring rasakan ketegangan keluar melalui kulit, otot-otot, tulang mapun sel-sel. Lakukan dengan media music, sehingga lebih cepat merasakan relaksasi dan music ini dapat diperoleh melalui $\mathrm{CD}$ atau youtube. Kemudian lakukan sikap pasrah dan pasif, hanya memperhatikan pikiran yang keluar masuk, dengan focus pada keluar masuknya nafas. Lakukan shavasana dengan nyaman jika diperlukan bantal dapat dilakukan, sehingga intinya adalah relaksasi dan lepasnya ketegangan.

\section{DAFTAR PUSTAKA}

Arif, Antonius, 2011. Hypno Therapy Scripts \& Strategies. Elex Media Komputindo: Jakarta.

Elfiky, Ibrahim, 2014. Terapi Berpikir Positif. Zaman: Jakarta.

Feuerstein, Georg, 2011. The Encycllopedia of Yoga and Tantra. Shambala: Colorado.

Gunawan, Adi W., 2015. Quantum Life Transformation. Gramedia: Jakarta.

Gunawan, Adi W., 2012. The Miracle Of Mind Body Medicine. Gramedia: Jakarta.

Gunawan, Adi W., 2012. Hypnotherapy, The Art of Subconscious Restructuring. Gramedia: Jakarta. 
Gunawan, Adi W., 2012. The Secret Of Mindset. Gramedia: Jakarta

Jean and Doriel Hall, 2015. The Practical Encyclopedia Of Astanga Yoga \& Meditation. Anness Publishing: London.

Kartini Kartono, 2013. Patologi Sosial Jilid 1. Raja Grafindo Persada: Jakarta.

Looker, Terry \& Gregson, Olga, 2005. Managing Stress (Mengatasi Stress Secara Mandiri). Baca: Yogyakarta.

McCall, Timothy, 2007. Yoga As Medicine (The Yogic Prescription For Health And Healing). Bantam Dell: New York.

Swami Satyananda Saraswati, 2012. Asana Pranayama Mudra Bandha. Yoga Publication trust: India.

Wong, WillY \& Hakim, Andri, 2009. Dahsyatnya Hipnosis. Visimedia: Jakarta. 